\title{
UN TEXTO DE AL-'AOQĀD (1889-1964) SOBRE BLASCO IBÁÑEZ
}

Por

MARCELINO VILLEGAS

Se trata de una reflexión sobre la obra y la vida del escritor español con motivo de su muerte; al-ªqqādla publicó el 10 de febrero de 1928; Blasco Ibáñez murió el 28 del mes anterior.

Los principales focos de atracción del artículo me parecen estos dos:

1) Que al-c'Aqqādse apoya en Blasco lbáñez para hablar de sí mismo y de la realidad egipcia.

2) Que se revela muy alejado de España y lo español, realidades exóticas para él.

El texto nos ofrece, pues, la oportunidad de ver algo nuestro en el espejo del otro (que se mira en el espejo que desde aquí se le brinda), un espejo que deforma, aunque mucho menos que los del callejón del Gato; la admiración es sincera, la implicación en los temas, mucho más; el tono lo da el frío doctoral de quien se ha pasado parte de la vida enseñando y la otra poniendo los puntos sobre las íes.

Quiere esto decir que el texto que presento vale más para conocer a al'Aqqād que para conocer a Blasco Ibáñez. Y es natural, ya que al-cAqqād lo ha escrito y Blasco Ibáñez es sólo la ocasión. Aunque el interés del artículo estriba no tanto en lo que dice como en que al-cAqqād lo escribiera.

Los temas que destaca son los suyos propios: el inconformismo, la mujer, la insobornabilidad, el amor, la intensidad de la experiencia, el rigor en la expresión. Cuando menciona el antimonarquismo y el anticlericalismo de 
Blasco lbáñez lo hace sabiendo que habla de cosas tan pertinentes en su pais que ni las subraya ni las disimula: son pura evidencia. Igual pasa con la maldad de la aristocracia.

Cuando habla del derecho de la mujer a vivir independiente se percibe un deje de extrañeza, el de quien ha predicado en el desierto; pero también el de quien no acaba de creérselo. al-c'Aqqād sigue, e incluso aplaude, la misoginia de Blasco Ibáñez, pues de misoginia se trata, aunque Blasco lbáñez le buscara razones sociales e históricas indudables a su rechazo. La aprobación de al-cAqqād no tiene, por cierto, nada de raro, ya que era misógino él mismo en un país donde hay intensas actitudes misóginas por la razón que Blasco lbáñez da al final de "Los cuatro hijos de Eva». Las mujeres egipcias han ideado disfraces sorprendentes a partir de las ideas de sus detractores, caricaturas que les permiten defenderse en la lucha; como las tentadoras y las mujeres de su casa que Blasco lbáñez ideó en sus novelas.

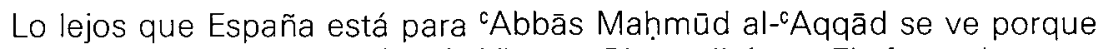
explica el nombre y los apellidos de Vicente Blasco lbáñez. El efecto de espejo frente a espejo arroja entonces imágenes jubilosas e instructivas, cuando al-cqqād interpreta como etnógrafo algo familiar para nosotros. En la traducción que sigue restablezco el uso habitual (Blasco lbáñez), aunque el original dice siempre lbáñez, menos en el título. Como se ve en la explicación que da, al-cAqqād conocía al escribir este artículo el valor de cada uno de los tres elementos que componen el nombre del escritor español, pero el contexto sugiere que al-cAqqād pensó un tiempo que Blasco era el nombre e Ibáñez el apellido.

El efecto de lejanía resulta más que de la cultura árabe misma (entonces la tendencia habría sido soldar los dos elementos del apellido), de que la comunicación se produce a través de una cultura intermediaria. Ocurre entonces que los datos han sufrido una primera adaptación o lectura y también que el receptor árabe no lee desde su cultura, sino desde su conocimiento y su relación con la cultura intermediaria; y la cultura que ésta le transmite como parte excéntrica de ella.

Una cosa que al-cAqqād ve claro en Blasco lbáñez es que vivió como un personaje de las novelas que escribía y además que las novelas que escribía eran igual que el personaje desmedido que Blasco Ibáñez hizo de sí. Lo que no logra al- ${ }^{\mathrm{A}} \mathrm{Aqqa} d$ es convencer de que ese personaje resultaba ejemplar, modélico; los datos que aduce para ello parecen sacados de una película o un libro no muy buenos sobre Hollywood en la época del cine mudo.

El artículo tiene un interés informativo al margen y es que menciona tres escritores prestigiosos y muy populares en la época que ahora no lo son, los caracteriza y los valora sucintamente desde aquella perspectiva.

"Blasco |báñez» forma parte del Sācāt bayna l-kutub the utilizado la edición de al-Maktaba I-cașrīya, Beirut-Sidón 1979, pp. 387-393). Las notas que 
aparecen al pie de la traducción son mias; en el texto he añadido las fechas de primera edición de las obras y las de nacimiento y muerte de los autores citados. Los títulos árabes de las obras de Blasco lbáñez que aparecen en el texto se apartan del original en el caso de: Cañas y barro (al-Garina I-hamrăa), La catedral (Zill al-kanīsa), y Entre naranjos (al-Fayaḍān). Las versiones de los fragmentos citados son del propio al-c'Aqqād a partir de la traducción inglesa; no traduzco estas citas, sino que reproduzco siempre el original. En todos los fragmentos citados hay supresiones, condensaciones, cambios de registro y tono y alguna adición; de la familia real dice la versión árabe no sólo que vive a costa del contribuyente y con más presupuesto que la enseñanza (que es lo que dice Entre naranjos), sino también que lleva «una vida de holganza y ocion (fĩ cayš l-kasal wa-l-bițāla).

De Blasco Ibáñez se han vertido al árabe sólo textos breves; el cuento traducido más antiguo que conozco lo incluyó Gānim ad-Dabbāg en su antología Qișas min al-Garb (Mosul 1950), tomándolo del inglés; en el número de noviembre de 1966 de la revista «al-Aqlām» (Bagdad), apareció "La condenada» (Dahịyat al-cadāla), traducido por Salīm Ṭāhā at-Tikritī. Fernando de Agreda me comunica que la revista "al-Anwār", de Tetuán, publicó en su número 15 (1949), una versión del capítulo XVI de La vuelta al mundo de un novelista (1921), dedicado a Indonesia; que a principio de los años 60 aț-Tāhir Aḥ mad Makkī tradujo y publicó en "al-Ahrām» (El Cairo) "La tumba de Alī-Bellús" (Ḍarāhn aš-šayj 'Alā), de Cuentos valencianos (O.C., l, pp. 83-86); y que Salī m Tāhā at-Tikritī hizo lo propio con "Venganza moruna" (Kafāfa š-šaraf), de La condenada y otros cuentos (O.C., I., pp. 138-141), en "al-cArabī" (Kuwait), número 203 (1975).

[Después de redactada esta introducción he encontrado dos traducciones de Blasco Ibáñez bastante anteriores a las arriba señaladas. Se trata de: «Hafla 'ars» (La cencerrada, de Cuentos valencianos. O. C., I, pp. 33-44), versión de 'Abd al-Lațîf an-Naššār, publicada en "ar-Risāla», 12 (15-7-1937, pp. 714-720) y de "«'Aŷūz aș-șūra I-mutaḥarrika» (La vieja del cinema, véase nota 5 al texto traducido), versión de Muhammad Maḥmūd ad-Dawwāra, publicada en la misma revista, 36 115-7-1938, pp. 631-648].

Tanta lentitud y tan escaso sentido de la oportunidad (todas estas traducciones se hacen cuando Blasco lbáñez ya no es quien fue), valoran por contraste la curiosidad intelectual y la capacidad para informarse de ${ }^{\mathrm{A}} \mathrm{Abb}$ ās Mahmūd al-cAqqād, mostrando que algo que en un principio parece actividad mecánica es en realidad meritorio resultado del esfuerzo personal.

\section{BLASCO IBÁÑEZ}

A principios de este año había cuatro célebres personalidades de la novela en el mundo; la supremacía en este arte les pertenecía y sólo alguno de ellos cuatro podía ser el rector de los narradores de todo el mundo. Eran el 
ruso Merezhkovski (1865-1941) (*), el inglés Hardy (1840-1928), el francés Bourget (1852-1935) y el español Blasco lbáñez (1867-1928).

Las cualidades de Merezhkovski proceden de su facultad para combinar arte, religión e historia de tal modo que la mezcla late con la sangre de la vida y se enjoya con las galas de la creación. En ninguna de sus novelas falta el enfrentamiento de religiones ni el paganismo del artista, que ensalza formas y cuerpos, ni la representación de los factores históricos como si fuesen personajes puestos por un magno autor en un vasto escenario. 0 como si las personas fueran estatuas creadas para adornar y ser contempladas. Es un mundo que se recorre como un museo lleno de paradigmas y tipos.

Las cualidades de Hardy proceden de la pasión por la sencillez del campo; de la fe en la predestinación, en que el destino es quien decide grandezas y miseriäs en la vida; de mostrar a las personas como juguetes en manos de la naturaleza, que los rompe y se divierte con ellos sin propósito definido; de fundir todo ello en un molde poético donde conviven el distanciamiento olímpico para con las emociones humanas y la humanidad de un poeta a quien las penas han dejado sin lágrimas.

Las cualidades de Bourget proceden de la habilidad para urdir los episodios de la novela y de la sutileza y la veracidad con que imagina los caracteres y aclara los recovecos de la conciencia, cosa en que a veces cae en lo prolijo; hasta tal punto que el lector no acaba de saber si le aburre o si el autor ha derivado de los personajes de la novela a sus estudios y sus teorías sobre la vida y la gente (1).

Pues las cualidades de Blasco Ibáñez son todas esas y muchas más. En alguna de sus novelas, en Sónnica, la cortesana (1901), por ejemplo, se asemeja a Merezhkovski en la manera de revivir la historia y de revestirla con las galas del arte; en la manera de llegar a la quintaesencia del paganismo y de la adoración de las formas y los cuerpos. En otras novelas, sin embargo, en Los muertos mandan (1909), Flor de mayo (1895), La horda (1905), Cañas y barro (1902), Entre naranjos (1900) y La bodega (1905) en especial (aunque, en general, ocurre en toda su producción), compite con Hardy en la descripción de la vida suburbana, de las preocupaciones de labradores y obreros y de paisajes abiertos. También se asemejaría a él en la fatalidad y en la burla del tiempo, si no fuera porque suaviza este tema con una compasión desconocida para el distante y ciego destino de Hardy, ajeno a cuantos sufrimientos $y$ esperanzas le rodean.

(*) Tanto en las obras de este escritor publicadas por Espasa Calpe en su Colección Austral, como en los diccionarios que he podido consultar, su apellido aparece transcrito Merejkovsky.

(1) Paul Bourget fue psicólogo además de novelista. Publicó unos Ensayos de psicología y unos Estudios de psicología contemporánea. Blasco lbáñez tiene un estudio sobre Bourget, aparecido en 1920. (Cfr. O.C., Aguilar, Madrid, 1967, 8. ${ }^{\text {a }}$ ed., pp. 1666-1679). El primer párrafo empieza así: «Una novela de Bourget (dejando aparte su tesis, que resulta simpática o antipática según las creencias del lector) es siempre una novela bien hecha, bien construida, con personajes que inspiran interés, con una acción interesante y dramátican. 
En la minuciosidad de la representación se parece a Bourget, pero sin la afectación ni la artificiosidad, sin nada de ese estilo doctoral que hace pensar en el quirófano y en el Tratado. Cuando lo que se tiene en las manos es una novela de Blasco lbáñez no se percibe en ningún momento que se está leyendo algo que un hombre ha escrito con el propósito de analizar las almas y de diseccionar diferentes tipos de emociones. Quien quiera hacer la prueba lo tiene a mano en todas las novelas, en todos los personajes, en todas las situaciones de este escritor; conseguido como sin esfuerzo, analizado sin parcialidad ni dispersión.

Si lo que se desea es deducir el protagonista tipo de todas las novelas de Blasco lbáñez se comprobará que éste consta de menos observaciones veraces y detalladas que los protagonistas de las novelas de Bourget; y puede costar esfuerzo familiarizarse con esta clase de protagonista, pero cuando se consigue se comprende que el análisis psicológico alcanza su mayor perfección cuando se produce sin señales de intencionalidad ni continuas llamadas de atención. Puede ocurrir que Blasco lbáñez se engolfe en la descripción y que persiga enseñar y dar lecciones olvidando la acción y los personajes; pero él se lo permite como quien relata oralmente se permite llamar la atención de los oyentes sobre algún tema al margen relacionado con su relato. $Y$ si los oyentes confían en la habilidad sin falla y en la amenidad del narrador para relatar y hacer digresiones le escucharán con total entusiasmo. $Y$ es indudable que pueden entusiasmar las muestras de la amplia curiosidad y de la experiencia de las cosas de este mundo que aparecen en las obras del espléndido escritor. Van de las prendas y las palabras de los hombres del mar a las de la historia pasada y presente, a las de la música, la filosofía y las artes, a las de la guerra y sus preparativos, a la biografía de grandes personalidades y escritores. Blasco lbáñez muestra un conocimiento sinigual de la vida de España (2) en todas las épocas y todas las regiones donde sus gentes han ido asentándose. $Y$ todo ello junto a una variedad natural y fácil en la composición de figuras de hombres y mujeres de todas las clases sociales, de todo tipo de caracteres y conducta. Sobresale particularmente en la composición de personajes femeninos, tanto si los condena como si atrae la simpatía hacia ellos porque sufren por el amor tormento. Salvo que se trate de mujeres de la depravada clase noble de su país, que desprecia, no perdiendo ocasión de incitar a sus compatriotas a vilipendiarla y a alzarse contra ella. A ésas no duda en privarles del don del amor y en someterlas a las pasiones, porque, como dice en su novela Los muertos mandan, a su modo de ver el amor requiere genio, exactamente igual que el arte o la poesía, y no todas las naturalezas están dotadas de esa genialidad ni todos los que hablan de ella están dotados para gozar de sus bellezas:

«¡El amor! Todos se creían con derecho a él y el amor era como el talento, como la belleza como la fortuna, una dicha especial que sólo gozaban contadísimos privilegiados... Por suerte, el engaño venía a ocultar esta cruel de-

(2) El original dice al-Andalus, pero el resto de la frase y que más adelante se refiera a al-Andalus como la "época musulmanan, no dejan duda de que aquí significa España. 
sigualdad, y todos los humanos acababan pensando nostálgicamente en la juventud, creyendo haber conocido realmente el amor, cuando no habían sentido otra cosa que el delirio de un contacto de epidermis» (3).

Blasco lbáñez da a la mujer aquello a que tiene derecho en el mundo y le reconoce la capacidad de plantearse las cosas de la vida lo mismo que los hombres. En su novela Los enemigos de la mujer (1919) queda sobremanera claro.

En su cuento "Los cuatro hijos de Eva" el narrador relata una visita que Dios hizo a Eva después de la expulsión del paraíso. Eva se prepara para recibirle, agradarle y recuperar la deferencia perdida. Luego avía a los preferidos y mete a los demás en el establo. ¡Y tenía tantos! La comitiva divina llegaba ya. Dios tuvo a bien conceder al primero de los niños presentes fuerza, al segundo elocuencia, al tercero justicia y al cuarto dinero. Y cuando, al ver que Dios se iba, Eva sacó a los demás del establo sucios y llorosos Dios les impuso trabajar eternamente para sus cuatro hermanos y servirles. A los que ordenó trabajar de continuo para los demás son los obreros y los siervos. En este punto un oyente hace una objeción al narrador:

«- ¿Y las mujeres? ¿Qué hace usted con las mujeres? (...) Eva seguramente tendría alguna vez hijas, pues de no ser así no existirian mujeres actualmente y las hay en todas partes (...) Lo que yo le pregunto es cuál fue la suerte de las hijas de Eva».

\section{Y el narrador le contesta:}

«Bien se ve $(\ldots)$ que el que ha hecho esa pregunta es joven y sin experiencia (...). Dios, con ser Dios, no puede dar nada a las mujeres (...). Después que están en el mundo su única esperanza es el hombre. Todo lo que son y lo que tienen se lo deben al hombre. Para ellas es el trabajo de los pobres, el poder de los que gobiernan, las hazañas de los soldados, el dinero de los millonarios. Ellas son las que tuercen con más facilidad la dureza de la Justicia... No; las mujeres no tienen que pedir nada a Dios, pues lo reciben de los hombres... Y los hombres cuando trabajan por la gloria, por la ambición o por amor al dinero no hacen en el fondo más que trabajar por ellas y para ellas» (4).

En este cuentecillo está resumida la opinión de Blasco lbáñez sobre las relaciones naturales entre hembras y machos, tanto pobres como ricos.

Blasco Ibáñez estaba tan dotado para el cuento como para la novela; a diferencia de otros narradores, que sólo son maestros en uno de los dos gé-

(3) I, ii. En O.C., ed. cit., II, p. 314.

(4) El cuento pertenece a El préstamo de la difunta y otros cuentos (1921). Cfr. O.C., II, pp. 1614-1627. Lo citado en pp. 1624 y 1627 . al- ${ }^{-A q q a ̆ d}$ menciona los dones en orden diferente al relato: «el poder de juzgar», "tú serás el hombre de guerra, el héroe», "tú dirigirás los negocios", "tú serás el Orador». "Los cuatro hijos de Eva" es tratamiento más extenso de un cuento anterior "El éstablo de Eva" (Cuentos valencianos, 1893). Cfr. O.C., 1, pp. 81-83. 
neros. Blasco lbáñez se centra en el estado psicológico y lo plasma en cuentos notables donde trabaja más la descripción y la representación que la anécdota y las situaciones. En mi vida olvidaré a la vieja que pierde a su nieto en la guerra y luego le ve en una película de ambiente bélico (5). Tampoco olvidaré su descripción de la grandeza de la maternidad en «El monstruo» (6). Ni la de la actitud del hombre apodado el Palomo en "TTalqa z-zalam». Ni la del obrero que cruza el desierto para cumplir la promesa que ha hecho a su santa madre (7). Tampoco olvidaré su descripción de "Noche servia" (8), ni la de "El empleado del cochecama». (9), ni la de la Virgen loca (10), ni la de los muchos personajes que ha descrito en sus cuentos del modo más sencillo, más hermoso y más auténtico. Son imágenes que se graban en las páginas de la memoria y que no se borran ni con la lectura de otros libros ni con las experiencias que deparan los días.

Cuando cité el nombre de Blasco lbáñez unido al de Thomas Hardy no podía suponer que tendría que deplorar la muerte del gran novelista muy poco después de haber deplorado la del gran poeta, pues ha querido la suerte que los dos grandes entre los grandes de la literatura de hoy se hayan ido en el curso de un mes (11). La pérdida que su muerte supone para las letras universales no se enjugará durante meses ni durante años.

Blasco lbáñez nació en la ciudad de Valencia el año 1867. El oficio para el que estudió fue la abogacía, pero el oficio en que empezó su actividad fue el periodismo. Ibáñez no es su apellido ni el apellido de su padre, sino el de su madre, pues en España el uso es que figuren en el nombre el apellido paterno y el apellido materno. Se formó en el amor a la libertad y la república y se contó entre los partidarios del estado cubano cuando en la isla se produjo el levantamiento en pro de la independencia. Los desórdenes que provocó la victoria cubana le obligaron a refugiarse en Italia escondido en un barco (bājira), pues su vida peligraba (12). Estuvo preso numerosas veces (13) y en la cárcel supo lo que es sufrir, el más amargo sufrir. Pero no varió de opinión ni cejó en su hostilidad contra el gobierno monárquico porque, como dice por boca del diputado de Entre naranjos, cuando interviene en su turno de orador, pensaba que:

«En el mantenimiento de la casa real se gastaba más que en enseñanza pública. El sostenimiento de una sola familia resultaba de más valía que el

(5) "La vieja del cinema" (El préstamo de la difunta y otros cuentos. O.C. II, pp 1566-1576).

(6) Id., pp. 1535-1538.

(7) No he conseguido iocalizar estos dos cuentos.

(8) El préstamo de la difunta y otros cuentos (O.C., II, pp 1549-1552).

(9) Id., pp. 1610-1614

(10) "Las virgenes locas», id., pp. 1562-1565.

(11) Thomas Hardy falleció el 11 de enero de 1928; Blasco Ibáñez el 28 del mismo mes y año.

(12) "Había ido a Italia disfrazado de marino, e hizo el viaje en un velero", citado en la biobibliografía de O.C., I, p. 11. Subrayado mío.

(13) «He estado preso unas 30 veces», id., p. 10. Entre 1930 y 1931 al 'Aqqāq pasó seis meses en la cárcel. 
despertar a la vida moderna de todo un pueblo. En Madrid, en la capital, a la vista de todos ellos, las escuelas instaladas en inmundos zaquizamís; iglesias y conventos surgiendo de la noche a la mañana como palacios encantados en las principales calles. En ventitantos años de Restauración, más de cincuenta edificios religiosos, completamente nuevos, estrechando la capital como una cintura de edificios flamantes; $y$, en cambio, una sola escuela moderna, como la de cualquier población moderna de Inglaterra o de Suiza» (14).

Estas $y$ otras verdades parecidas pone en boca del diputado liberal en la Cámara. Ellas eran las que le hacían aborrecer el régimen monárquico y clerical y las que le impulsaron a combatir sin tregua ni cuartel ambos poderes. Él mismo fue diputado y pronunció discursos parecidos en la Cámara, para la que fue elegido siete veces como representante de Valencia, su lugar de origen. Su aversión a los alemanes y su apoyo a los aliados durante la guerra mundial, con sus escritos y novelas, quizá fuera resultado de su indignación contra los reyes germanos que impusieron en su país un régimen despótico y clerical. Los frailes eran dueños de la mitad de la tierra, que explotaban y esquilmaban sólo por aparentar y por capricho. Contra tales reyes hizo la más dura requisitoria en su novela La catedral (1903), haciéndoles responsables de la postración y la miseria en que cayó la península después de haber florecido y haber nadado en la opulencia durante la época musulmana (15).

Los suyos reconocieron que era sincero, que su pesar era auténtico, y le amaron hasta la adoración. Le invitaron a dar conferencias sobre literatura y arte en América del Sur y en el puerto de Buenos Aires le recibieron 80.000 personas que le dieron la bienvenida con el respeto que se usa con las autoridades y con el amor que se usa con los padres. Recorrió aquellos lugares de norte a sur e instó a sus habitantes a colonizar lo que por colonizar estuviere. La respuesta que le dieron fue favorable y se apresuraron a llevar a la práctica sus consejos. Así conquistó el mundo de la agricultura y la industria igual que había conquistado el mundo de las letras y la política. No obstante, no soportó mucho tiempo la política, cuyas intrigas y artificios le afligían como no podía ser menos en un reformador independiente y honesto. Acabó por aborrecerla, y la confianza en su utilidad para regenerar y renovar vaciló. Se consagró, pues, al saber y las letras en exclusiva y gastó en ambos su esfuerzo, su fama y su riqueza. Sólo en una cosa siguió creyendo: en la piedad por sus compatriotas ignorantes y pobres y en el castigo de sus injustos y cobardes tiranos. Vivió odiado por éstos, desterrado en la frontera con su país. Su casa estaba en una hermosa colina. Allí escribía cartas y novelas; desde allí alquilaba aeroplanos para hacer llegar pasquines a las gentes de ciudades y pueblos que no tenían acceso a sus libros, sus cartas, sus novelas.

Y murió en el exilio.

No creemos que tuviera un credo preciso con que tranquilizarse como

(14) III, ii. O.C., I, pp. 676-677

(15) O.C., I., pp. 1003 y ss; especialmente 1003-1004. 
se tranquiliza el fiel con su credo religioso. Porque, según dice en su novela Mare Nostrum (1918), consideraba que:

"Todas las religiones se desmenuzaban al sufrir un frío examen, $y, \sin$ embargo, producían santos y mártires, verdaderos superhombres de la moral. Todas las revoluciones resultaban defectuosas e ineficaces al quedar sometidas a una revisión científica, y, no obstante, habian engendrado los mayores héroes individuales, los más asombrosos movimientos colectivos de la Historia (...). Nacer, crecer, procrearse y morir no bastaba para crear una historia: todos los animales hacian lo mismo. El hombre debe añadir algo más que sólo él posee: la facultad de imaginarse el porvenir... ¡Soñar! Al patrimonio de ilusiones legado por los hombres anteriores había que agregar una nueva ilusión o un esfuerzo para realizarla» (16).

El credo de Blasco Ibáñez era la confianza en esa capacidad; la regeneración de su patria que es el pivote en torno al cual giraba su credo. Cuando se desencadenó la gran guerra su deseo fue que la victoria de los aliados supusiera la consolidación de la libertad y la caída de las monarquías obsoletas. Por ello se dedicó en cuerpo y alma a sustentar la causa de los aliados: visitó el frente muchas veces y escribió Los cuatro jinetes del Apocalipsis (1916), que hizo volar su fama de oriente a occidente y de la que se ha dicho que es el libro de mayor circulación después de la Biblia. No quiso preocuparse de hacer fortuna con ella y se la vendió a un periodista americano en 60 guineas (17); una novela que ha dado al editor miles y miles. Pero lo que a él le preocupaba era la causa de la justicia y la libertad, porque creía en ella. $Y$ porque venciera nunca flaqueó ni escatimó nada de cuanto estaba en su mano; ni el talento ni los bienes que poseía.

¡Un hombre que era gloria de su patria ha muerto lejos de ella! ¡Qué lección! El mañana nos hará comprender lo que de esencial hay en ella; algo que se ha repetido muchas veces: luchar por la mejora nunca es estéril.

\section{0 de febrero de 1928}

\footnotetext{
(16) XII, O.C., 1i, p. 1211

(17) Un funcionario medio ganaba mensualmente 17 guineas en el Egipto de la época. Las 60 guineas serían unos 25 dólares. Blasco lbáñez conservó, no obstante, para si los derechos de adaptación cinematográfica; y siguió de cerca la realización de Los cuatro jinetes del Apocalipsis (1921). Cfr. Jeanne, René y Ford, Charles, Histoire illustrée du cinéma muet (Marabout, Verviers 1981, p. 230).
} 